\title{
The Gulf Strachan Decision: Potential EFFects on Producers, Facility OWNers, Straddle Plant Owners and NOVA
}

\section{PATRICK M. COLWELl}

This article outlines the decision of the Alberta Energy and Utilities Board to allow a slipstream of gas to be reprocessed in Gulf Canada's Strachan Plant. The positions of the interveners and the potential effects of the decision on interested parties are examined. It is suggested, however, that the conditions imposed might make the project 100 difficult and expensive to execute.
$L$ 'article décrit la décision de l'Alberta Energy and Utilities Board permettant qu'un courant gazeux glissant [slipstream] soit traité de nouveau à l'usine Gulf Canada de Strachan. La position des intervenants et les répercussions possibles de la décision pour les parties intéressées sont examinées. $L$ 'auteur note toutefois que les conditions imposées pourraient rendre l'exécution du projet excessivement difficile et onéreuse.

\section{TABLe of ConTENTS}

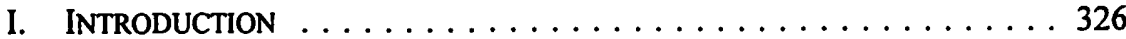

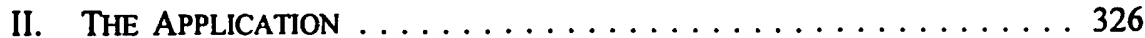

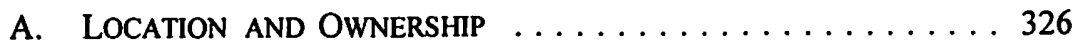

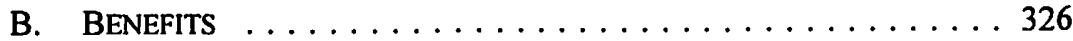

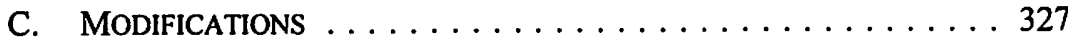

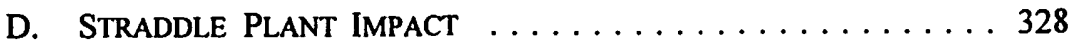

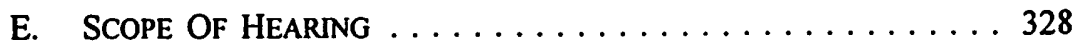

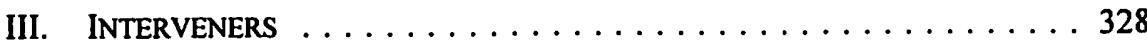

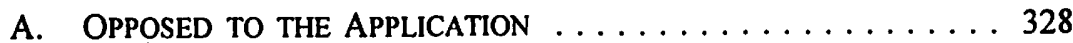

B. IN FAVOUR OF THE APPLICATION . . . . . . . . . . . . 329

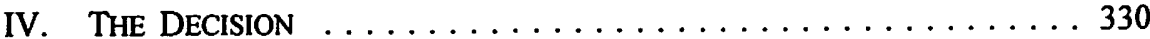

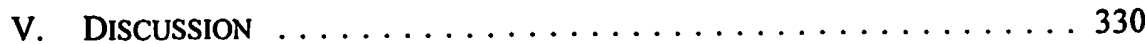

A. LEGAL ENTITLEMENT AND THE NOVA TARIFF . . . . . . . 330

B. ECONOMIC BENEFIT AND RESOURCE CONSERVATION . . . . . . 340

C. UPSTREAMING AND NGL BUSINESS RULES . . . . . . . . . . . 346

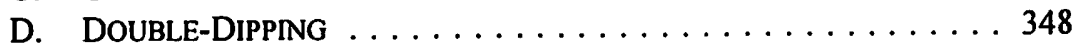

E. COMPONENT-TRACKING ................ 349

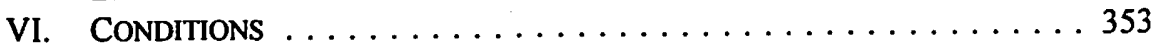

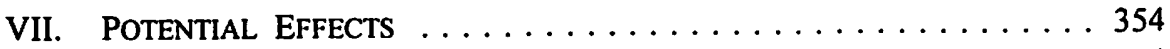

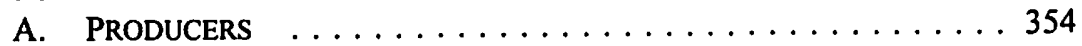

B. FACILITY OWNERS .................. 355

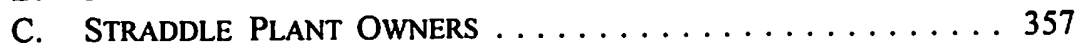

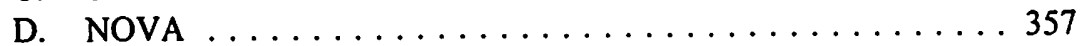

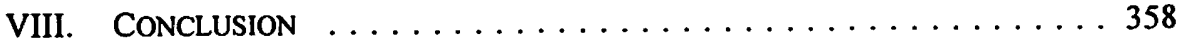

Senior Solicitor, PanCanadian Petroleum Ltd., Calgary, Alberta. 


\section{INTRODUCTION}

The purpose of this article is to examine the decision of the Alberta Energy and Utilities Board (the Board) to allow a slipstream of gas to be reprocessed in the Strachan Gas Plant.

First, the application of Gulf Canada Resources Ltd. is examined. Then, the arguments made before the Board by Gulf and the principal interveners are discussed. Finally, the potential impacts of the decision on producers, facility owners, straddle plant owners and NOVA Gas Transmission Ltd. are reviewed.

\section{The Application}

Pursuant to an application dated 26 June 1995, Gulf applied to the Board for an amendment to Approval No. 6253B respecting the Strachan Plant.'

This was the second time that Gulf had filed an application to amend Approval No. 6253B; the first was filed with the Board on 11 May 1994. In August of 1994, the Board had requested that Gulf meet with the interested parties to review the first application. It was subsequently withdrawn on 2 February 1995.

In the Application, Gulf, as the operator of the Strachan Plant, requested the amendment of Approval No. 6253B to allow modifications to the Strachan Plant to allow a "slipstream" of gas from the NOVA system of up to 5917 thousand cubic metres ( 210 million cubic feet) per day to be reprocessed at the Strachan Plant for the recovery of $\mathrm{C}_{3}+$ and $\mathrm{C}_{5}+$ (natural gas liquids or NGLs).

\section{A. LOCATION AND OWNERSHIP}

The Strachan Plant is located southwest of Rocky Mountain House. It is owned by Gulf, Talisman Energy Inc. and, at the time of the Application, Amerada Hess Canada Ltd. $^{2}$

\section{B. BENEFITS}

Gulf referred to the benefits of the plant modification:

(1) increased plant utilization and process efficiencies;

(2) reduced per unit operating costs;

(3) increased liquid recoveries;

1 Gulf Canada Resources Lid. Strachan Gas Plant Approval Amendment, NGTL Gas Sidestreaming Application (26 June 1996), Decision No. D96-7 (A.E.U.B.) [hereinafter Decision D96-7]; Application No. 950983 (26 June 1995) [hereinafter the Application].

2 The ownership of the Strachan Plant changed before completion of the hearing. Pengrowth Gas Corporation acquired an interest of 1.494743 percent and Petro-Canada acquired the interest of Amerada (26.831486 percent). 
(4) extended economic life of the Strachan Plant;

(5) enhanced recovery from the fields being served by the plant; and

(6) net economic benefit to the province and the local economy. ${ }^{3}$

In the Application, Gulf stated that the participating owners of the Strachan Plant would only sidestream gas from NOVA which they owned or controlled.

\section{ModifiCations}

The modifications to the Strachan Plant were described as being limited to a tie-in to the deep cut facilities, approximately 500 metres of process piping, additional metering and possible equipment modifications in the deep cut process area. ${ }^{4}$ The Application did not contemplate that any ethane would be removed from the sidestream.

The Application also required that the Strachan Plant owners construct a two kilometre pipeline from the NOVA system to the Strachan Plant to transport the sidestream of gas to the Strachan Plant. The costs of this tie-in were to be paid for by the Strachan Plant owners. Once this gas was reprocessed at the Strachan Plant, the residue gas would be transported back to the NOVA system on the existing sales gas line.

The "Strachan Gas Facilities Functional Unit Block Flow Diagram" from the Application shows the proposed modifications.

\section{STRACHAN GAS FACILITIES FUNCTIONAL UNIT BLOCK FLOW DIAGRAM}

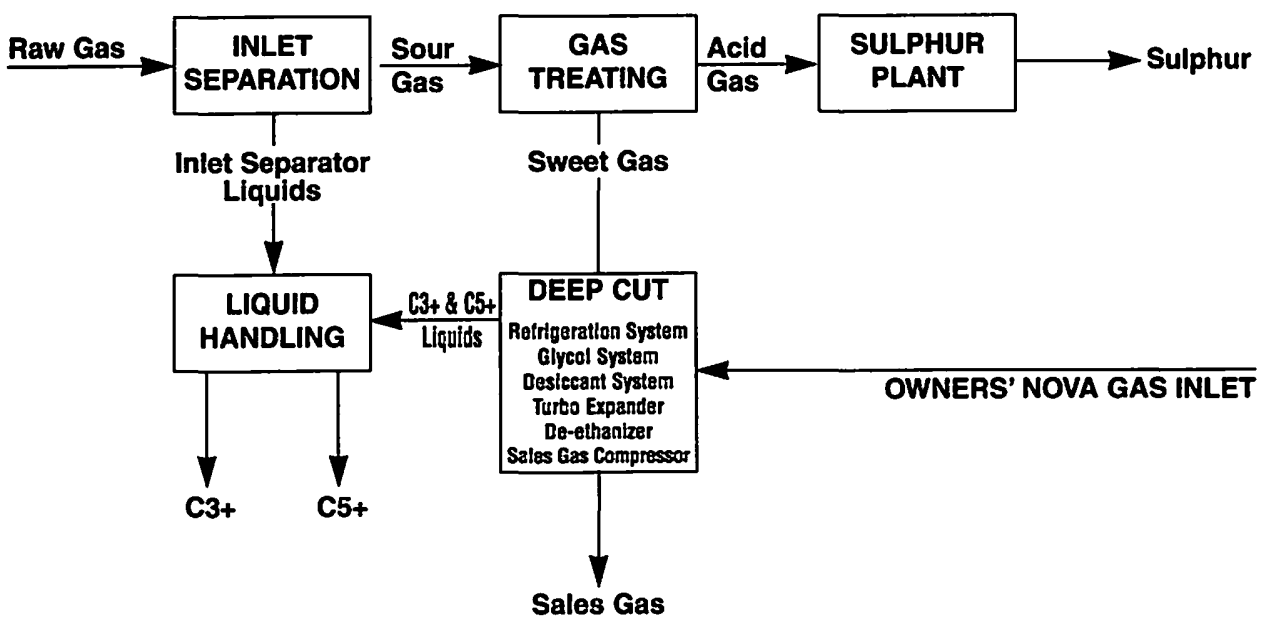

Application, supra note 1 at 4 .

Ibid. at 5. 


\section{Straddle Plant Impact}

Gulf argued that the impact on the straddle plant system would be minimal and that, in any event, it had the legal right to access its gas on the NOVA system for the purpose of removing NGLs, notwithstanding the effects to the straddle plant owners.

Gulf stated that:

(1) the amount of NGLs which would be removed was small;

(2) overall extraction efficiency was not affected;

(3) it had a legal right to access its gas for removal of NGLs;

(4) the gas which Gulf injected into the NOVA system was richer than the average gas composition in the NOVA common stream; and

(5) this project was unique, and the Application would result in very few, if any, other applications of a similar nature. ${ }^{5}$

\section{E. SCOPE OF HEARING}

The Board conducted a pre-hearing meeting to determine the issues to be dealt with at the hearing. Gulf had proposed that only issues relating to the specifics of the Application should be heard by the Board. The Board recognized the potential policy implications of Gulf's Application, particularly on the straddle plant owners. It concluded that it would accept and consider relevant information from interested parties regarding policy matters affecting the straddle plants, including the cumulative effects upon the straddle plants or provincial gas transportation systems. ${ }^{6}$

\section{INTERVENERS}

\section{A. Opposed to the Application}

\section{HUSKY OIL OPERATIONS LTD.}

Husky intervened as the operator and majority working interest owner of the Ram River gas processing plant. This plant is located thirteen kilometres from the Strachan Plant. The two plants are connected by a sour gas pipeline which was constructed to allow Gulf to direct gas volumes owned or controlled by Gulf and other working interest parties from Ram River to the Strachan Plant.

Husky indicated in its intervention that the Ram River plant was capable of processing all of the gas currently delivered to the Strachan Plant but that it did not have facilities for extraction of NGLs.

Ibid. at 12.

Decision D96-7, supra note 1 at 2.

Ibid., Intervention of Husky Oil Operations Ltd. (31 January 1996) [hereinafter Husky Intervention]. 


\section{Alberta Natural Gas Company LTD. (ANG)}

ANG intervened as the managing partner of the Cochrane Extraction Plant Partnership, the owner of the Cochrane Straddle Plant. The plant reprocesses gas streams from both the NOVA mainline and Zone 7 of the Foothills PipeLines Ltd. pipeline.

\section{3. amoco Canada Petroleum Company ltd. (Amoco)}

Amoco intervened as a major producer (1.1 billion cubic feet per day in 1995) and shipper on NOVA (544 million cubic feet per day upstream of the Strachan Plant) and a straddle plant owner and operator (48.81 percent ownership of the Empress I plant; 100 percent ownership of the Empress I expansion; operator of the Empress II plant and ownership interest in the Empress Gas Liquids Joint Venture plant operated by Wolcott Gas Processing Ltd.).

\section{Alberta ENERGY COMPANY LTD. (AEC) AND \\ PanCANADIAN PETROLEUM Limited (PCP)}

AEC and PCP filed a joint intervention in which they were described as large gas producers, shippers on the NOVA system (AEC with 500 million cubic feet per day and PCP with 700 million cubic feet per day) and operators of a variety of field processing facilities.

AEC and PCP also have interests as straddle plant owners and AEC is a part owner of the Alberta Ethane Gathering System.

\section{PETRO-CANADA}

As a result of its acquisition of Amerada, Petro-Canada became an owner of the Strachan Plant but did not join in the application with Gulf et al. It intervened as a producer, a shipper on NOVA (400 million cubic feet per day), plant owner and operator, and as a straddle plant owner.

\section{TransCanada Gas Services Limited (TCGS)}

TCGS intervened as the largest single shipper on NOVA ( 3 billion cubic feet per day) on its own behalf and as agent for TransCanada PipeLines Ltd. as a party to various extraction agreements with the straddle plant owners.

\section{B. In Favour of the Application}

Canadian 88 Energy Corp.;

Crestar Inc.;

Canadian Hunter Exploration Ltd.;

Chevron Canada Resources; and

Imperial Oil Company Ltd. 
These parties supported the Application. They are all producers of gas and shippers on the NOVA system.

\section{THE DECISION}

The hearing ran from 27 February 1996 until 7 March 1996. The Board rendered its decision (D96-7) on 26 September 1996.

The decision allowed Gulf's application, subject to four conditions. The specifics of the conditions are outlined to below. ${ }^{8}$

As of the date of preparation of this article (May 1997), Gulf had not yet implemented the proposal.

\section{Discussion}

In making its decision, the Board reviewed a number of specific areas. These can be summarized under the following subheadings:

- Legal Entitlement and the NOVA Tariff

- Economic Benefit and Resource Conservation

- Upstreaming and NGL Business Rules

- Double-Dipping

- Component-Tracking

Each of these areas will be discussed in turn.

\section{A. Legal ENTItLEment aNd the NOVA TARIFF}

Gulf took the position that it had the right to access and remove NGLs from its gas on the NOVA system. It claimed that it had this right at common law and under the terms of the NOVA tariff. In this article, references to the NOVA tariff will mean the NOVA Gas Transportation Tariff, made up of the General Terms and Conditions and the various rate schedules and appendices.

\section{LEGAL ENTITLEMENT}

Gulf characterized the relationship between a shipper and NOVA as one of bailment. Bailment is the legal relationship which arises when one party takes possession of another party's chattels for some limited purpose short of a transfer of title. ${ }^{9}$

See generally E.L.G. Tyler \& N.E. Palmer, Crossley Vaines on Personal Property, 5th ed. (London: Butterworths, 1973) at 70; and B. Ziff, Principles of Property Law, 2d ed. (Toronto: Carswell, 1996) at 277-80. 
There are certain elements which must be present in order for a bailment to be established. While these will vary depending upon the nature of the relationship, they are:

(1) possession must be acquired by the person to be charged as bailee;

(2) possession may be acquired by delivery of the chattels by the bailor to the bailee;

(3) for possession to pass by delivery there must be a receipt and acceptance and a common intention that possession shall pass;

(4) in every case the identical goods bailed must be redelivered or otherwise applied in specie by the bailee; and

(5) otherwise the mode in which the bailee's possession is to be determined does not affect the establishment of a bailment. ${ }^{10}$

Gulf argued that as the bailor, at common law and under the NOVA tariff, it had the right to direct NOVA to deliver its gas to the Strachan Plant for reprocessing. This, according to Gulf, was not materially different than the direction from other shippers to NOVA to deliver their gas to the straddle plants for NGL extraction. Since Gulf had no right or ability to interfere with those arrangements, the interveners had no right to interfere, intervene or restrain the arrangement between Gulf and NOVA."

While Gulf's characterization of the relationship with NOVA may be correct, it is questionable whether or not the relationship between Gulf and NOVA could be determinative of Gulf's rights. While Gulf took the position, both in the pre-hearing phase and at the hearing, that no third parties' rights were affected by the Application, it is incontrovertible that both the straddle plant owners and the other shippers on the NOVA system would be affected by the approval of the Application, even if such an effect would be slight. This was confirmed by the Application itself which stated there would be fewer NGLs available to the straddle plants. ${ }^{12}$ As a result, the relationship between Gulf and the other shippers would seem to be of more importance than the relationship between Gulf and NOVA. ${ }^{13}$

Tyler \& Palmer, ibid. at 79-84.

Decision D96-7, supra note 1 at 3.

Application, supra note 1 at 12 .

Gulf's Application was made under s. 26(1)(b) of the Oil and Gas Conservation Act, R.S.A. 1980, c. 0-5. Under the Oil and Gas Conservation Regulations, Alta. Reg. 151/71, when such an application is made, s. 9.020(3) provides that "where it appears to the Board that its decision on the application ... may directly and adversely affect the rights of any person, the Board shall hold a public hearing or publish notice of the application...." Gulf argued that no other party's rights were affected by the Application and therefore a hearing was not required. This position was opposed by the interveners in the pre-hearing process. They claimed that their rights were clearly affected by the Application and that, in any event, the requirement was that their rights "may" be affected, not that they "must" be affected. 


\section{OWNERSHIP OF THE COMMON STREAM}

Gulf and the interveners agreed that the gas injected into the NOVA system was held by the shippers on NOVA in common ownership. Notwithstanding the admission of such common ownership, as set out above, Gulf took the position that the sidestreaming at the Strachan Plant was allowed under the NOVA tariff and did not affect any third party rights. The straddle plant owners and Husky advanced a different view of the parties' respective rights. They argued that the sidestreaming of the gas to recover the NGLs would be unlawful, since all shippers have a right to the common stream and Gulf's proposal would give it exclusive access.

\section{JOINT TENANCY VERSUS TENANCY IN COMMON}

Most of the jurisprudence relating to joint tenancy and tenancy in common is in the context of real property, rather than personalty. While many of the principles arising from the real estate cases will be applicable in the context of personalty, ${ }^{14}$ there are some technical differences. In addition, the cases dealing with real estate often do not translate well into the context of the ownership of chattels, especially in a case such as this where such ownership is directly related to and affected by the terms and conditions of the NOVA tariff.

Tenancy in common is most often described in contrast to joint tenancy. ${ }^{15}$ Joint tenancy requires that the four unities be present. These are the unity of interest (each interest is of equal nature, interest and duration); the unity of title (each interest arises under the same instrument); the unity of time (each interest vests at the same time); and the unity of possession (each owner holds undivided possession of the whole property). ${ }^{16}$

Tenancy in common requires only one unity, the unity of possession. As a result, each co-tenant is entitled to an undivided interest in and to the property. According to Sir Edward Coke, "Onely this propertie is common to both, viz. that their occupation is individed, and neither of them knoweth his part in severall." 17

A tenancy in common is created in the following ways: if the parties acquire the property with an express limitation that they take as tenants in common; by a limitation which vests the estates at different times; by variance of a joint tenancy without partition; or, by acquiring title by possession. ${ }^{18}$ The common law held that where there was no express limitation in a grant, there was a presumption of joint tenancy. This

Ziff, supra note 9 at 309.

A.H. Oosterhoff \& W.B. Rayner, Anger and Honsberger, Real Property, 2d ed. (Aurora: Canada Law Book, 1985) at 822; Ziff, ibid. at 292; E.H. Burn, Cheshire and Burn's Modern Law of Real Property, 15th ed. (London: Butterworths, 1994) at 221.

While Ziff, ibid. at 292 refers to the purpose of the unities as being "obscure," he does confirm that Canadian courts have treated the four unities as being "carved in (Black)stone."

The First Part of the Institutes of the Laws of England (Or, a commentary upon Littleton) (1832; New York: Garland, 1979) at 189.

Oosterhoff \& Rayner, supra note 15 at 818; Stringer v. Phillips (1730), 21 E.R. 1053. 
presumption has been reversed by statute, ${ }^{19}$ but applies only to real property. In the case of personalty, the presumption of joint tenancy continues. ${ }^{20}$

In the case of deliveries of gas to NOVA, clearly the ownership in the common stream is not held in joint tenancy, since the unities of time, title and interest are not present.

While the decision of the Board indicates that all parties, including the Board, were in agreement that the gas in the NOVA system is held in tenancy in common, there is little discussion as to how this conclusion was reached. What is the legal basis for such a result? The NOVA tariff does not specifically state that by delivering gas into the NOVA system a shipper becomes a tenant in common in the entire gas stream, hence there is no indication that a shipper acquires any interest in the property of any other shipper. How is such a fundamental conclusion reached, and is it justified under the circumstances existing on the NOVA system and under the NOVA tariff?

\section{CONFUSION}

Support for the position that the shippers on NOVAs hold interests as tenants in common is found in the doctrines of "confusion," or "intermixture," which are derived from the Roman law doctrines of commixtio and confusio. ${ }^{21}$ Commixtio occurs where dry goods owned by different parties are combined or mixed together. Confusio occurs where liquids, again owned by different parties, are mixed together. The distinction between these two doctrines is one of degree, i.e. the smaller the molecules which are mixed together - for example, gas molecules versus lumber or grain - the more difficult it is to separate them and determine their ownership. However, there does not appear to be any distinction between the doctrines at common law, and therefore they will be referred to as a single doctrine of mixture. ${ }^{22}$

At one time, the result of the application of the law related to mixtures depended (and still does to a certain extent) on how the mixing occurred. For example, it was previously the case that where a mixture of goods had occurred due to the negligence or wrongful act of one party, the wrongdoer lost its entire interest in the property. ${ }^{23}$

19 Law of Property Act, R.S.A. 1980, c. L-8, s. 8.

20 Ziff, supra note 9 at 309.

21 See A.G. Guest, "Accession and Confusion in the Law of Hire-Purchase" (1964) 27 Mod. L. Rev. 505; Ziff, supra note 9 at 84-85.

See generally Guest, ibid:; P. Matthews, "Proprietary Claims at Common Law for Mixed and Improved Goods" (1981) 34 Cur. Leg. Prob. 159; R.B. Slater, "Accessio, Specificatio and Confusio: Three Skeletons in the Closet" (1959) 37 Can. Bar Rev. 597.

$23 \quad$ Colwill v. Reeves (1811), 170 E.R. 1257; Jones v. De Marchant (1916), 28 D.L.R. 56 (Man. C.A.). This position has now been softened somewhat so that the wrongdoer will not lose its entire interest in the mixture, but rather the property in question will be held as a tenancy in common and the innocent party is entitled to receive from the mixture the same quantity of goods which it put into the mixture. See Indian Oil Corp. Lid. v. Greenstone Shipping S.A. (Panama), [1987] 3 All E.R. 893 (Q.B.) [hereinafter Indian Oil] relating to a mixture of oil, and McDonald v. Lane, [1882] 7 S.C.R. 462, dealing with a mixture of logs. 
An example of a case in which goods of a similar value were innocently mixed is Jackson v. Anderson. ${ }^{24}$ In that case, the plaintiffs were the successors of Sadler, Jackson \& Co. They had consigned to Mr. J. Fielding in "Buenos Ayres" a shipment of linen goods for sale. Fielding sold the goods and sent 1,969 Spanish dollars back to Sadler, Jackson \& Co. These dollars were loaded in a barrel containing, in total, 4,718 Spanish dollars. Fielding advised Sadler, Jackson \& Co. that he had delivered to Messrs. Laycock \& Co. a bill of lading for the barrel.

After repeatedly inquiring about the status of the barrel, the plaintiffs found that it had been received by Laycock \& Co. and subsequently had been deposited at the Bank of England. The bank purchased the dollars and credited the account of Laycock \& Co. with the proceeds. The plaintiffs demanded the return of the 1,969 Spanish dollars, but the defendant refused on the grounds that the plaintiffs could not identify which of the 4,718 dollars in the barrel belonged to them. The plaintiffs brought an action to recover the 1,969 dollars.

Mansfield C.J. found in favour of the plaintiffs. He indicated that if the barrel had remained in the possession of Laycock \& Co. then clearly the plaintiffs would have been entitled to the recovery of the dollars. Since all of the dollars had been disposed of, there was no question as to whether any portion owned by the plaintiffs had been retained. Mansfield C.J. said:

It is not like the case of tenants in common, who have a right to a part of every grain of corn, etc. Here, one has a right to a certain number, and the other to the rest. If a man keeps all, and has no right to a part, the action lies for that part, which he wrongfully detains. ${ }^{2 s}$

While co-ownership was denied in Jackson v. Anderson, ${ }^{26}$ it has been argued that the courts have tailored their findings in order to give the innocent parties involved in a mixture a remedy. This is described as follows:

Jackson v. Anderson was a case where neither A nor B was at fault in the mixing, and where B converted the whole. In such a case the parties are not in the same position: $B$ is in possession and $A$ is out of it. Possessory actions must be brought by A against B. A and not B must prove his case, which is why he generally has to wait until B converts the whole mixture. Similarly, if neither A nor $B$ is in possession of the whole, say $C$ has it, and either $A$ or $B$ sues alone, it is obvious that, on the above reasoning, the plaintiff will succeed where $C$ disposes of the whole. But if $C$ converts only part, or if $\mathrm{C}$ has only part and converts all that part, neither A nor B suing separately will normally be able to show that their property has been converted.... Yet remark: if both sued jointly they must succeed, since between them they must own every particle of the mixture. This, then, is the reasoning that led the courts in cases where both the owners were out of possession of the mixture, to regard each of them as co-owner, a tenant in common, so that each could sue separately. ${ }^{27}$

Ibid.

Matthews, supra note 22 at 165 [emphasis added]. 
The leading case dealing with an innocent mixing of goods of the same or similar value is Sandeman \& Sons v. Tyzack and Branfoot Steamship Co. ${ }^{28}$ Bales of jute to be shipped from India were consigned to various consignees. Each bale was marked with a number. The bill of lading stated that the bales were received "marked and numbered as per margin." The shipment contained 28,002 bales.

When the ship arrived, four of the consignee's deliveries were deficient by a combined total of fourteen bales. However, there were eleven bales which formed part of the shipment but which were not identified as having been shipped under any of the bills of lading. The ship owners argued that the eleven bales should be apportioned among the consignees who had not received their entire shipment. Sandeman \& Sons refused to accept the apportionment of $2 \frac{1}{2}$ bales to their short delivery of bales and the ship owners brought an action for the freight charges, arguing that while Sandeman \& Sons were entitled to a set-off for the failure to deliver the bales, it was limited to charges relating to $3 \frac{1}{2}$ bales and not six bales, as argued by the defendant.

Lord Moulton reviewed the principles of English law which applied to the consequences of mixing goods. Where A's goods are mixed with B's due to the fault of $\mathrm{B}$, then $\mathrm{A}$ can claim the goods. ${ }^{29}$ If the mixing

\footnotetext{
has taken place by accident or other cause, for which neither of the owners is responsible, a different state of things arises. Neither owner has done anything to forfeit his right to the possession of his own property, and if neither party is willing to abandon that right, the only equitable solution of the difficulty, and the one accepted by the law, is that "A." and "B." become owners in common of the mixed property."
}

Lord Moulton went on to refer to the uncertainty surrounding the determination of the relative interests of the parties ${ }^{31}$ and concluded that such cases were: "little more than instances of cutting the Gordian knot - reasonable adjustments of the rights of parties in cases where complete justice was impracticable of attainment." 32

[1913] A.C. 680 (H.L.).

Subject to the subsequent decisions such as Indian Oil, supra note 23.

Supra note 28 at 695.

For example, in Buckley v. Gross (1863), 122 E.R. 213 where tallow of different owners melted during a fire and leaked out of separate warehouses and combined in the sewers before flowing into the River Thames, the court per Blackburn J. found that the various owners were tenants in common in equal shares. In Spence v. Union Marine Insurance Co. Ltd. (1868), L.R. 3 C.P. 427 where markings on cotton bales rendered them indistinguishable, the court per Bovill C.J. found that the mixture of bales resulted in the parties becoming co-owners in proportion to their respective interests.

Supra note 28 at 695. 
Further, the court held that there was no basis for compelling Sandeman \& Sons to be a co-owner in the remaining eleven bales of jute. This conclusion has been referred to as "a 'fiddle', but one eminently justifiable in the circumstances."

On the basis of this authority, the Board's conclusion seems well founded. The NOVA tariff itself generally appears to be neutral, i.e. neither supporting a tenancy in common nor indicating any contrary result.

\section{Rights of a TENANT IN COMmON to THE COMMON PROPERTY}

The straddle plant owners and Husky argued that all the shippers on the NOVA system were the owners of the gas and unless and until this common ownership was severed, Gulf did not have any right to access the gas for NGL extraction, or for any other purpose. Such severance would occur when the gas was delivered under the terms of the NOVA tariff. Since the Gulf sidestreaming did not contemplate paying a delivery charge, the interveners concluded that the delivery which NOVA would make to Gulf was not a "delivery" within the meaning of the NOVA tariff. ${ }^{34}$

Where a party is a tenant in common, what are its rights to access the property for its own purposes; and if it does so, what are its responsibilities to its co-owners? While the straddle plant owners and Husky argued that the proposal by Gulf would be unlawful, there is ample authority which indicates that a co-tenant can use the chattels held in co-tenancy, without the permission of the other co-owners, provided that such co-tenant does not exclude the other tenants, and subject to the obligation to account if it receives more than its share of the benefits of the property. ${ }^{35}$

Matthews, supra note 22 at 165 . Quare whether it can be argued that the combination of gas with different levels of NGLs produces a distinct chattel, separate and apart for the components making up the mixture. This type of combination is dealt with under the doctrine of alteration or specificatio in Roman law. See generally: Matthews, supra note 22; Ziff, supra note 9; RozenbergGreenbaum, "Specifications, Comminglings and Confusions: The Joining of One Chattel to Another" (LL.M. Thesis, York University, 1991); P. Mathews, "'Specificatio' and the Common Law" (1981) 10 Anglo-Am. L. Rev. 121; E.C. Amold, "The Law of Accession of Personal Property" (1922) 22 Columbia L. Rev. 103.

Alteration generally arises where some labour is applied to a chattel which has the effect of transforming it into a different chattel, such as making grapes into wine. The tests that have developed to determine whether alteration has occurred include the reversibility of the combination and whether it is possible to trace the specific chattels. It does not appear that the combination of different gas components would result in a chattel so substantially transformed as to bring into play the doctrine of alteration. It is also likely that if it were to apply in this case, the result would be no different than under the doctrine of confusion, i.e. the parties would own the resulting chattel as co-owners in proportion to their respective contributions. See: Wylie \& Lochhead v. Mitchell (1870), 8 M. 552 (Ct. Sess., Scot.), a case dealing with accessio, resulting in a finding of tenancy in common.

34 Decision D96-7, supra note 1 at 5.

is Statute of Anne (1705), 4 Anne c. 16, s. 27, provides that "Actions of Account shall and may be brought and maintained ... by one Joint Tenant, and Tenant in Common, ... against the other, as Bailiff for receiving more than comes to his just Share or Proportion." See generally Oosterhoff \& Rayner, supra note 15 ; Ziff, supra note 9. 
In Henderson v. Eason, ${ }^{36}$ Edward and Robert Eason held farm land as tenants in common. Edward Eason was in possession of the property and received the whole of the rents derived from the property and never accounted to his co-owner, Robert, for any share of the proceeds. Upon Edward's death, Robert brought an action against the executor of Edward's estate for an accounting under the Statute of Anne. ${ }^{37}$

The court, per Parke B., found in favour of the estate of Edward. Under the Statute of Anne, a tenant in common is only liable to account to the other tenants in common if it receives money or something else, which the co-tenants are entitled to receive simply by reason of being tenants in common, and if that co-tenant has received more than its proportionate share. ${ }^{38}$

Possession or occupation alone of the common property will not be enough to trigger a right to an accounting. The court referred to some examples of such occupation in which a tenant in common would not be liable to account for its occupation:

For instance, if a dwelling house, or barn, or room, is solely occupied by one tenant in common, without ousting the other, or a chattel is used by one cotenant in common, nothing is received; and it would be most inequitable to hold that he thereby, by the simple act of occupation or use, without any agreement, should be liable to pay a rent or anything in the nature of compensation to his cotenants for that occupation or use to which to the full extent to which he enjoyed it he had a perfect right. ${ }^{39}$

While this indicates that occupation alone would not be enough to create a right of compensation in the other tenants in common, Gulf clearly desired to do more than merely occupy the property. The sidestream would remove NGLs from the commonly owned stream and thereby reduce the overall value of the commonly held property to all the owners. The court ruled that such utilization would not necessarily fall within the terms of the statute:

[T] here are many cases where profits are made, and are actually taken, by one cotenant, and yet it is impossible to say that he has received more than comes to his just share. For instance, one tenant employs his capital and industry in cultivating the whole of a piece of land, the subject of the tenancy, in a mode in which the money and labour expended greatly exceed the value of the rent or compensation for the mere occupation of the land; in raising hops, for example, which is a very hazardous adventure. He takes the whole of the crops: and is he to be accountable for any of the profits in such a case, when it is clear that, if the speculation had been a losing one altogether, he could not have called for a moiety of the losses, as he would have been enabled to do had it been so cultivated by the mutual agreement of the cotenants? The risk of the cultivation, and the profits and loss, are his own; and what is just with respect to the very uncertain and expensive crop of hops is just also with respect to all the produce of the land, the fructus industriales, which are raised by the capital and industry of the occupier, and would not exist without it. In taking all that produce he cannot be said

(1851), 117 E.R. 1451.

Supra note 35.

Supra note 36 at 1458.

Ibid. 
to receive more than his just share and proportion to which he is entitled as a tenant in common. He receives in truth the return for his own labour and capital, to which his cotenant has no right. ${ }^{40}$

In Grinde v. Grinde, ${ }^{41}$ an action was brought by a wife against her husband for rents arising from the use of their farm following the parties' separation. The title to the property was held in joint tenancy.

The Alberta Supreme Court, per Steer J., followed the decision of the Manitoba Court of Appeal in Osachuk v. Osachuk $k^{42}$ in finding that under the Statute of Anne an accounting between co-owners may be required:

(1) When one co-owner has actually excluded the other and wrongfully prevented her from having the use of the common property.

(2) Under the Statute of Anne, when one co-owner has received more than her share of the rents or other revenues of the common property, she must account for such excess, but only such as has actually been received by her from some tenant or other third party. This rule does not apply to profits made by a coowner via her own use and occupation of the common property.

(3) When one co-owner occupies and uses the common property under some agreement whereby she becomes bailiff or agent of the other so that she must account to him for her share of the profits.

(4) When one co-owner occupies the common property as tenant of the other's share, and owes rent to her accordingly. In this case, she is answerable during the period of the agreed tenancy, and also during any period during which she holds over after the end of the tenancy.

The court held that the wife could not bring an action for an accounting for the occupation of the property, since the husband had not prevented her from occupying the land, so there was no ouster. Also, since the husband had not claimed for the expenses incurred in operating the farm, the wife could not bring an action for rent.

In the Application, Gulf was careful to deal with the possible argument that it would be taking more than its rightful share of the benefit of the common stream by agreeing that it would only process gas which belonged to the Strachan Plant owners, and by stating that the composition of the gas which the owners injected into the NOVA system was significantly richer in liquids than the average NOVA gas. ${ }^{43}$ Both of these representations appear to be directed at ensuring that Gulf did not take more than its proportionate share of the benefit from the common property.

The Board accepted that "title to individual gas molecules is lost once a shipper injects gas into the NGTL system. It appears the shipper retains ownership of a proportion of the common stream, and the NGL contained therein, based on his total 
deliveries into the NGTL system." 44 Since Gulf was only going to access its proportionate share of the common stream, and not deny any other common owners to access their share (i.e., Gulf did not acquire any exclusive privilege), its sidestreaming was permissible.

\section{NOVA TARIFF}

Closely related to the issue of legal entitlement to the NGLs in the NOVA common stream was the issue of the NOVA tariff and whether it did or did not accommodate the proposed sidestream.

Gulf took the position that the sidestream could be carried out under the existing NOVA tariff. The delivery of gas from NOVA to the Strachan Plant was not the delivery to a "Delivery Point," and the redelivery of the gas onto NOVA after reprocessing was not delivery to a "Receipt Point" as those terms are defined in the NOVA tariff. As a result, there were no charges payable by Gulf for redelivery of the reprocessed gas stream. ${ }^{45}$

Gulf characterized its relationship with NOVA as one of bailment and argued that, as its bailee, NOVA was obligated to follow Gulf's direction so long as it did not contravene the terms of the NOVA tariff. ${ }^{46}$

Gulf pointed out that NOVA had agreed to provide the service that was necessary in order to complete the sidestreaming ${ }^{47}$ and that there were safeguards to other shippers on the system so that NOVA could not offer an unjustly discriminatory or unduly preferential rate or service to any particular customer. ${ }^{48}$

The straddle plant owners proposed that any assessment of Gulf's rights had to be undertaken in the context of the NOVA tariff. The NOVA tariff does not contemplate the sidestreaming of gas for a number of reasons:

(1) the NOVA tariff deals only with energy content and not liquids;

(2) in order for a shipper to receive back its share of the energy content, it required a "Delivery" under the NOVA agreements;

(3) since Gulf would not be taking delivery as contemplated in the NOVA tariff, it could not sidestream the gas; and

(4) the distinction between Gulf's sidestream proposal and the activities of the straddle plants is that the straddle plants reprocess gas which is then redelivered to the shippers. The straddle plants do not take delivery as a part owner of the common stream. ${ }^{49}$

44 Decision D96-7, supra note 1 at 7.

45 Gulf's Response to ANG's Information Request No. 11.

4 Decision D96-7, supra note 1 at 3.

$4 \quad$ Ibid. at 3.

48 Ibid. at 4.

49 Ibid. at 5-6. 
The Board concluded that Gulf's agreements with NOVA allowed for the sidestreaming. The Board took a pragmatic approach in its analysis of the arguments respecting legal entitlement to the common stream and compliance with the NOVA tariff. The Board pointed out that straddle plant owners acquire the right to extract NGLs by virtue of contract. The straddle plant owners did not dispute Gulf's right to receive its share of NGLs produced at the straddle plants from a common stream. Therefore, a producer should be able to remove NGLs at a location other than at a straddle plant to the extent:

(1) that it is eligible to extract NGLs in the field;

(2) its entitlement to NGLs is extracted at the straddle plants; and

(3) there are no restrictions for other public interest reasons. ${ }^{50}$

The Board could not identify any reason why the NOVA tariff should act to prevent sidestreaming. The NOVA tariff's requirement of a delivery and receipt point charge for sidestreaming at the Strachan Plant, where the straddle plants do not pay such cost, would be "undue discrimination" in favour of the straddle plants. ${ }^{51}$

\section{B. ECONOMIC BENEFIT AND RESOURCE CONSERVATION}

Amoco, ANG, PCP, AEC and Petro-Canada filed a report by Wright-Mansell Research Ltd. entitled The Economic Implications of Sidestreaming NOVA Gas. ${ }^{52}$

The purpose of the report was to examine several scenarios and determine the costs and benefits of each. There was a "no-bypass" scenario, (in which it was assumed that the volumes which were sidestreamed at the Strachan Plant were reprocessed at the straddle plants), and a "bypass" scenario (in which it was assumed that a volume of gas equal to that sidestreamed at the Strachan Plant would bypass the straddle plants).

In addition to these, two royalty cases were considered. "Royalty Case A" assumed that participating Strachan Plant owners would pay royalties on the NGLs produced and would receive a credit for the shrinkage volumes. "Royalty Case B" assumed that the NGLs were royalty paid (i.e. treated like liquids extracted at the straddle plants). ${ }^{53}$

The overall conclusion of the WMR Report was that sidestreaming had a negative impact on Alberta and Canada, even in the most favourable scenarios.

The study assumed that in the no-bypass scenario there would be a minor incremental amount of NGLs recovered (ninety barrels per day), but that such

Ibid. at 7.

lbid. at 8 .

(January 1996) [hereinafter WMR Report].

Gulf argued in a report of Confer Consulting Ltd. that the only relevant scenario was the nobypass, Royalty Case A scenario, since Gulf had never assumed that there would be a physical bypass of the Strachan Plant reprocessed stream (in fact, it had assumed that such a reprocessing would occur in calculating the incremental NGL volumes which would result from sidestreaming), and that Gulfs expressed intention was to pay royalties on the NGLs derived from sidestreaming. 
incremental recovery was more than offset by the losses to other parties, principally the straddle plant owners. This led to the conclusion that the sidestreaming had a negative economic impact overall. (Under Royalty Case A, Alberta actually benefited by the increased royalties paid on the NGLs recovered at the Strachan Plant, but this gain was offset by reduced tax revenue). These effects are shown in Table 8 of the WMR Report: ${ }^{54}$

TABLE 8 - ANNUAL IMPACTS OF SIDESTREAMING AT STRACHAN ON SOCIETY (all values in millions of dollars)

\section{NO BYPASS}

Net Benefit to:

Gulf

Straddle Plants

Provincial Government

Total Benefit to Alberta

Federal Government

Total Benefit to Canada (Net Social Benefit)

\begin{tabular}{|c|c|c|c|}
\hline Case A & Case B & Case A & Case B \\
\hline 1.71 & 2.85 & 1.71 & 2.85 \\
\hline-3.41 & -3.41 & -6.26 & -6.26 \\
\hline 1.35 & -0.29 & 0.69 & -0.95 \\
\hline-0.35 & -0.84 & -3.86 & -4.36 \\
\hline-0.74 & -0.24 & -1.97 & -1.47 \\
\hline-1.08 & -1.08 & -5.83 & -5.83 \\
\hline
\end{tabular}

BYPASS

The WMR Report considered the benefit which Gulf would derive from the Strachan Plant sidestreaming. Using the increased NGL volumes derived from the sidestream and assuming a value for such liquids and the costs of shrinkage, transportation, fractionation and incremental operating expenses, the after-tax profit to Gulf varied between $\$ 1,710,000$ (Royalty Case A) to $\$ 2,860,000$ (Royalty Case B). The study concluded that this would allow Gulf to recover the estimated capital costs of the sidestream $(\$ 700,000)$ within the first year.

The WMR Report also examined the economic effects if other facilities were also allowed to sidestream the NOVA common stream. The plants which were considered were those in close proximity to the NOVA mainline with: significant quantities of upstream gas; excess capacity; suitable processing equipment to remove NGLs (i.e., a turbo expander preferably); facilities for handling NGLs; and access to an NGL pipeline. $^{55}$

Table 11 of the WMR Report shows "Plants That Could Economically Sidestream NOVA Gas in the Immediate Term in Isolation":56

s4 Supra note 52 at 16.

ss The potential candidates were examined in the report by Purvin \& Gertz Inc., Preliminary Assessment of Alberta Gas Plants Which Could Process NOVA Gas (January 1996), prepared for ANG, Amoco, AEC, PanCanadian and Petro-Canada. 
TABLE 11 - PLANTS THAT COULD ECONOMICALLY SIDESTREAM NOVA GAS IN THE IMMEDIATE TERM IN ISOLATION

TURBO EXPANDER PLANTS

\begin{tabular}{|c|c|c|c|c|c|}
\hline & $\begin{array}{c}\text { Available } \\
\text { Capacity } \\
(1000 \mathrm{~m} 3 / \mathrm{d}) \\
\end{array}$ & $\begin{array}{c}\text { Potential } \\
\text { NGL } \\
\text { Recovery } \\
\text { (m3/d) }\end{array}$ & $\begin{array}{c}\text { Capital } \\
\text { Cost } \\
\text { (MM\$) } \\
\end{array}$ & $\begin{array}{c}\text { Annual } \\
\text { After Tax } \\
\text { Profit } \\
\text { (MM\$) }\end{array}$ & $\begin{array}{c}\text { Present } \\
\text { Value } 10 \\
\text { Years - 10\% } \\
\text { (MM 1995\$) }\end{array}$ \\
\hline Gulf Strachan & 5917 & 357 & 0.70 & 1.71 & 9.79 \\
\hline Shell Waterton & 4583 & 277 & 0.60 & 1.31 & 7.44 \\
\hline Chevron Kaybob S. & 2415 & 146 & 0.46 & 0.57 & 3.05 \\
\hline Imperial Wapiti & 2197 & 133 & 0.46 & 0.52 & 2.74 \\
\hline Cdn Hunter Karr & 1811 & 109 & 0.46 & 0.42 & 2.10 \\
\hline Amoco Ricinus & 1558 & 94 & 2.07 & 0.42 & 0.50 \\
\hline Crestar Wembley & 1177 & 71 & 0.39 & 0.28 & 1.32 \\
\hline Imperial Pembina & 834 & 50 & 0.50 & 0.24 & 0.97 \\
\hline Conoco Peco & 490 & $\underline{30}$ & 0.39 & 0.13 & 0.41 \\
\hline Total - T.E. Plants & 20982 & 1267 & & & \\
\hline \multicolumn{6}{|c|}{ NON-TURBO EXPANDER PLANTS } \\
\hline & $\begin{array}{c}\text { Available } \\
\text { Capacity } \\
(1000 \mathrm{~m} 3 / \mathrm{d})\end{array}$ & $\begin{array}{c}\begin{array}{c}\text { Potential } \\
\text { NGL }\end{array} \\
\text { Recovery } \\
\text { (m3/d) }\end{array}$ & $\begin{array}{c}\text { Capital } \\
\text { Cost } \\
\text { (MM\$) } \\
\end{array}$ & $\begin{array}{c}\text { Annual } \\
\text { After Tax } \\
\text { Profit } \\
\text { (MM\$) }\end{array}$ & $\begin{array}{c}\text { Present } \\
\text { Value } 10 \\
\text { Years - 10\% } \\
\text { (MM 1995\$) }\end{array}$ \\
\hline Anderson Carstairs & 7649 & 231 & 1.16 & 0.79 & 3.72 \\
\hline Mobil Harmattan Elk & 6721 & 203 & 1.65 & 0.64 & 2.30 \\
\hline Amoco Kaybob S. & $\underline{4328}$ & $\underline{131}$ & 1.02 & 1.02 & 1.22 \\
\hline Total - N.T.E. Plants & 18698 & 564 & & & \\
\hline TOTAL & 39683 & 1831 & & & \\
\hline
\end{tabular}

Assuming that these plants were engaged in simultaneous sidestreaming (thereby progressively reducing the NGLs available for the next sidestream reprocessor), the net losses to Alberta would be as illustrated in Table 13 of the WMR Report: ${ }^{.7}$ 


\begin{tabular}{|c|c|c|c|c|c|c|}
\hline \multicolumn{7}{|c|}{$\begin{array}{l}\text { TABLE } 13 \text { - NET SOCIAL BENEFIT OF SIDESTREAMING } \\
\text { NOVA GAS BY ALL IMMEDIATE CANDIDATES } \\
\text { (present values in millions of } 1995 \$ \text {, discounted to } 1 \text { July 1996) }\end{array}$} \\
\hline & \multicolumn{3}{|c|}{ ALBERTA PERSPECTIVE } & \multicolumn{3}{|c|}{ CANADIAN PERSPECTIVE } \\
\hline Scenario-Royalty Case & $\underline{5 \%}$ & $\underline{10 \%}$ & $\underline{15 \%}$ & $\underline{5 \%}$ & $10 \%$ & $15 \%$ \\
\hline No Bypass - Case A & -55 & -46 & -39 & -91 & -75 & -63 \\
\hline No Bypass - Case B & -72 & -60 & -51 & -91 & -75 & -63 \\
\hline Bypass - Case A & -188 & -152 & -126 & -271 & -218 & -179 \\
\hline Bypass - Case B & -205 & -165 & -137 & -271 & -218 & -179 \\
\hline
\end{tabular}

The WMR Report also indicated that the future potential for sidestreaming is great in that, as raw gas reserves served by a particular facility decline, the ability to sidestream volumes increases. This would increase with facility modifications to allow for increased sidestream volumes and the addition to the list of some significant facilities (e.g., Shell's Caroline and Anderson's Dunvegan facilities) contingent upon reserve declines or facility modifications.

In addition to arguing that the sidestreaming would have a net negative economic benefit, the interveners challenged the efficiency of this use of processing capacity.

Husky's intervention focused on the Gas Plant Utilization Task Force (PUTF), which was initiated in 1991 by Gulf, Husky and Shell Canada Limited. The purpose of PUTF was to improve the efficiency of sour gas processing in South Central Foothills region. Ultimately, PUTF expanded to include Amoco, Petro-Canada and Mobil Oil Canada.

Husky outlined a scenario which had been identified by PUTF as a possible rationalization strategy. This involved directing all Strachan raw gas volumes to Ram River for processing. All Strachan Plant sulphur and raw gas processing (except inlet separation) were shut down and new compression and pumping capacity installed to divert Strachan Plant inlet fluids to Ram River through the existing line and a new liquids line. Minor modifications would be required at the Ram River plant. The results

indicate an annual combined Ram River and Strachan gross operation cost reduction in the order of $\$ 10$ million after allowance for operating costs for the remaining and new facilities at Strachan. Further, at an estimated capital cost of $\$ 11.5$ million, payout of capital occurs in less than two years and at industry average forecast prices, Husky's analysis indicates netbacks at Ram River for both Strachan and Ram River gas as improved in comparison to continued processing at Strachan. ${ }^{\text {s8 }}$

Husky argued that the PUTF had not progressed to a point where Gulf's application could be properly assessed and, therefore, the application was premature and should not be approved. 
Husky took the position that the sidestreaming of gas would entrench processing overcapacity since the facility owner's incentive to rationalize its assets was significantly reduced. Husky also argued that the Board's plant proliferation policy ${ }^{59}$ was broad enough to include existing facilities and should direct the Board to arrive at the same conclusion respecting overcapacity in a particular area as it would in considering new construction: that is, it argued that the Board's ultimate decision should reflect a bias towards rationalization of existing facilities. ${ }^{60}$

Petro-Canada argued that the Board should develop a set of criteria which would be applied to assess applications, such as Gulf's, in light of declining raw gas streams to underutilized plants and the straddle plant system as it currently functions. Such a policy would:

(1) promote efficient gas processing operations through enhanced recovery, consolidation, rationalization, re-sizing, cost reduction, etc.; and

(2) address the circumstances under which sidestreaming would be appropriate, which would require a review of:

(a) all gas source options available to a plant facing depleting reserves;

(b) other processing options, including re-sizing operations, reduction of operating costs, enhanced recovery of field gas, rationalization and increased utilization of other more efficient facilities;

(c) the need for the sidestream project;

(d) proof of increased NGL recovery;

(e) the reduction in processing opportunities or competition for processing unconnected raw gas due to sidestreaming;

(f) the overall social and economic effect of the project and the effect on the environment;

(g) proof that the party sponsoring the project "has demonstrated a clear legal right" to access NGLs in the NOVA common stream; and

(h) how the project sponsor will measure, track and inventory the NGLs it injects into the NOVA system and those it removes to prevent double dipping. ${ }^{61}$

Petro-Canada applied its proposed criteria to the evidence of Gulf and found it wanting in virtually all respects.

Gulf countered the position that the Board's plant proliferation policy should prevent its Application from succeeding by arguing that:

(1) the policy applied only to new plants and not to existing facilities like the Strachan Plant;

(1) Intervention of Petro-Canada (31 January 1996) at 9-10 [hereinafter Petro-Canada Intervention]. 
(2) the Board should encourage efficient utilization of existing facilities, which Gulf's Application would since it allowed the continued operation of the Strachan Plant;

(3) the sidestreaming reduced the per unit cost in the deep cut portion of the Strachan Plant as well as the unit processing cost of raw gas;

(4) continued operation of the Strachan Plant would allow for the production of reserves which might not otherwise be produced; and

(5) lower per unit production costs would attract other raw gas volumes and encourage exploration in the area. ${ }^{62}$

Gulf stated that it favoured the sidestreaming alternative to the rationalization proposals of Husky and indicated that it would not negotiate facility rationalization through the regulatory process.

The Board sided with Gulf on questions of efficient use of resources. It stated that the Board's plant proliferation policy ${ }^{63}$ was intended to apply to new processing capacity, rather than to existing facilities.

The Board did indicate that it supported continued rationalization of existing facilities but recognized that such rationalization involved a number of different considerations. The Board saw Gulf's Application as beneficial in that it increased plant utilization, increased resource depletion in the area and could possibly increase processing efficiency. ${ }^{64}$

The Board rejected the proposal of Petro-Canada that an applicant such as Gulf demonstrate a net economic and social benefit flowing from its application. The Board concluded that, depending upon the assumptions applied, the net effect of the Strachan Plant Application would be either marginally beneficial or marginally detrimental but in neither was it necessary for an applicant to establish a "significant and unequivocal net social" benefit. ${ }^{65}$

The Board also accepted that, since field plants are designed to process raw gas, such processing will provide the best economic returns to the owners. The Board considered the processing of gas from the NOVA common stream as being an economically lessdesirable option which should not be allowed unless Gulf could satisfy the Board that it was continuing to try to attract raw gas volumes to the Strachan Plant. ${ }^{66}$

The Board did provide some comfort to the straddle plant owners by stating:

Given the diverse resource base, the multiple ownership of the resource, and the different economic circumstances of each producer, the Board anticipates that the reprocessing needs which the straddle

\footnotetext{
62 Decision D96-7, supra note 1 at 9.

63 Supra note 59.

in Decision D96-7, supra note 1 at 11.

is Ibid. at 12.

(x) Ibid.
} 
plants fill in Alberta will continue to be necessary and the straddle plants will remain viable operations well into the future. The Board sees a viable straddle plant system as being in the public interest. ${ }^{67}$

While the Board did not adopt the criteria proposed by Petro-Canada, it did indicate that it has recognized the possibility of future applications for approval of sidestreaming schemes and has provided some indication of how such schemes would be treated from a policy perspective:

It would be of significant concern if this application, and its possible successors, were to constitute a threat to the long-term viability of the straddle plant system. The Board believes however, that if future applications continue to be restricted to existing facilities and are structured to limit the sidestream volumes to proprietary gas of the gas plant owners, as proposed by Gulf, the number of applications will be limited.... In principle, the Board would only see merit in sidestreaming if it involved no new grass roots facilities or if other public benefits existed. The Board would be concemed if significant third party gas were sidestreamed at the expense of the straddle plant system. ${ }^{68}$

The concern for the straddle plant owners was tempered somewhat by the Board's view that sidestreaming applications, even if undertaken to the extent proposed in the Purvin \& Gertz evidence, ${ }^{69}$ would not be significant to the straddle plants, since most of the likely candidates for sidestreaming were also straddle plant owners. The Board concluded that, in the long term, the straddle plant owners were in a "position to protect their commercial interests through contracts with producers."

\section{UPSTREAMing AND NGL Business RULES}

In their interventions and in their written evidence, ANG, AEC and PCP argued that there is a recognized classification of plants in the province. Field plants are those which extract NGLs prior to the delivery of specification gas into NOVA. ${ }^{71}$

ANG defined straddle plants as:

(1) being located near border points to ensure that gas leaving the province is reprocessed;

(2) being engaged in processing gas from the common NOVA stream for the benefit of all parties having an interest in the common stream at the point of export from the province;

(3) allocating rights to the gas processed at the straddle plants on the basis of nominations at the applicable NOVA export point;

(4) obtaining the authorization of shippers whose gas is transported past the straddle plants on the NOVA system to extract those shippers' liquids;

7 Intervention of ANG (31 January 1996) [hereinafter ANG Intervention]; Written Evidence of AEC and PCP (31 January 1996) [hereinafter AEC \& PCP Evidence]. 
(5) compensating the shippers for their respective pro rata share of the liquids extracted from the common stream at the particular straddle plant location; and

(6) being configured so as not to upstream one another.

ANG, AEC and PCP argued that the Strachan Plant would be a "hybrid," in that it would be removing NGLs from the common stream transported on NOVA. ${ }^{72}$

Other interveners also followed this argument. Amoco indicated that as a straddle plant owner it accepted certain commercial risks, such as reduced NGLs content in the NOVA stream due to field plant extraction; however, it did not accept the risk of a leaner common stream due to a field plant acting as a straddle plant. It suggested that if the Strachan Plant were to be allowed to operate in such a manner, it should be subject to the same controls as were the other straddle plants, such as having a prohibition upon reinjecting gas upstream of the existing straddle plants. ${ }^{73}$

Amoco expressed scepticism about Gulf's claim that it favoured raw gas processing over sidestreaming. Amoco pointed out that the deep cut modifications to the Strachan Plant proposed by Gulf would allow it to increase the capacity from 225 million cubic feet per day to 275 million cubic feet per day. This, Amoco believed, indicated an intention on Gulf's part to continue to operate the Strachan Plant exclusively as a sidestreaming facility once the turndown rate of 65 million cubic feet per day of raw gas throughput was reached, which Amoco estimated would occur in 2001. This was in spite of Gulf's assertions that it would not contract for third party gas solely to recover liquids at the Strachan Plant. ${ }^{74}$

Amoco characterized Gulf's proposal as treating the NOVA common stream like a bank, in which there are numerous deposit locations with withdrawals occurring at a single point. ${ }^{75}$

The effect upon Amoco as a straddle plant owner was described in terms of a leaner gas stream, increased costs and the prospect of numerous other applications to sidestream gas from the NOVA common stream.

AEC and PCP emphasized that the straddle plant system, from both contractual and regulatory points of view, has developed to recognize and protect the interests of the parties involved - including NOVA - producers and straddle plant owners. The Gulf proposal did not comply with the "interlinking conditions" which govern straddle plant operation. For example, Gulf's redelivery would not be subject to a receipt point charge. While this is consistent with the treatment of straddle plants, those plants reprocess gas for the shippers on the NOVA system as a whole, and not on behalf of one party, as Gulf proposed in its application. This was referred to as Gulf "seizing upon the

Ibid.

Submission of Amoco (31 January 1996) [hereinafter Amoco Submission].

Ibid.

lbid. 
advantageous aspects of the straddle norm while disclaiming any responsibility for the accompanying disadvantages." 76

TCGS, along with other interveners, argued that it was unfair that Gulf should be able to access the NOVA common stream, and reduce the value of such stream overall, with no compensation to the remaining shippers on the system. ${ }^{77}$ In order for the other shippers to remain whole, it would be necessary for NOVA to track the components in the gas received on and delivered from the system. This would ensure that the shippers who had not removed NGLs from the common stream would not end up owning a share of a common stream where the value had been reduced. ${ }^{78}$

Gulf took the position that its proposal would not fundamentally affect the straddle plant industry as it had been developed in the province. In response to the concerns of the straddle plant owners respecting NOVA Inventory Transfers (NITs) and the possibility of circumventing its undertaking to process only its own gas, Gulf agreed that any NITs which it carried out would be conditional on the purchaser not entering into an NGL extraction contract.

The Board acknowledged that Gulf's Application was unique and that it was not within the template of contractual relationships which had developed in the NGL/straddle plant industry. Notwithstanding this, the Board ruled that the changes which would flow from Gulf's Application would not be particularly onerous or costly to enforce, and that such changes should not hold up the Application.

With respect to Gulf's undertaking respecting conditional NITs, the Board recognized that such transactions had not been carried out before. The Board accepted that conditional NITs would not necessarily prevent double dipping, but the Board said it expected Gulf to "work diligently with NGTL and the other shippers to ensure that future contracts are designed so as to address the concerns raised by the interveners." 79

\section{Double-Dipping}

Concern was expressed by various interveners that Gulf's Application would allow it to "double-dip," i.e., that Gulf would be able to remove NGLs from its proportionate share of the NOVA common stream and then receive a proportionate share of the revenue derived from NGL extraction at the straddle plants. The interveners argued that such a double dip was unfair and that it negatively affected other shippers, since a leaner gas stream would increase processing costs at the straddle plants. ${ }^{80}$

AEC \& PCP Evidence, supra note 71.

Intervention and Prepared Direct Evidence of TransCanada Gas Services Ltd. (31 January 1996) [hereinafter TransCanada Intervention].

Ibid. at 6.

Decision D96-7, supra note 1 at 17.

TransCanada Intervention, supra note 77 at 6-8; Petro-Canada Intervention, supra note 61 at 11; ANG Intervention, supra note 71 at 6-7; Amoco Submission, supra note 73 at 5. 
Gulf's Application anticipated this argument, and in it Gulf agreed that the participating owners in the Strachan Plant would only process gas that belonged to them and that such owners would not contract the volumes sidestreamed at the Strachan Plant for processing in the straddle plants. Gulf stated that the gas it injected into the NOVA system was "significantly richer in liquids than the average NOVA gas. Even after extraction of liquids at the plant at the maximum rate applied for, the owners uncontracted gas on the NOVA system will continue to be richer than the average gas on the system."

Gulf did not propose a physical bypass of the straddle plants of an equivalent volume as that processed at the Strachan Plant.

Gulf also indicated that, to avoid any double-dipping, any NITs which it conducted would be conditional upon Gulf retaining the entitlement to NGL extraction. This proposal was attacked by the interveners ${ }^{82}$ as being unworkable (since it was outside the boundaries of the existing NOVA framework), and as being difficult to police (since multiple NITs of the same notional volume are possible prior to the volume reaching the straddle plants). TCGS argued that the limitation which Gulf conceded, i.e., that the Strachan Plant would only accept owners' gas, was not a valid safeguard to other shippers on the system. It did not matter that Gulf was processing gas which was owned by a third party because, in the absence of a component-tracking system, the effect on other shippers on the system was the same. ${ }^{83}$

TCGS suggested that Gulf's proposal to not contract for extraction of the volumes processed at the Strachan Plant was inadequate. While a component-tracking mechanism would treat Gulf's share of the gas as having no NGLs in it, and would allocate the NGLs in the Gulf volumes to the remaining shippers, a system to allocate such volumes does not exist. ${ }^{84}$

The Board recognized the potential for double-dipping by Gulf. The conditions which the Board imposed upon its approval of the application required Gulf to prevent such double-dipping and required that the benefits of any of the reprocessed volumes at Strachan should be distributed amongst the other shippers. The Board also recognized that the limitation which Gulf had proposed for conditional NITs (i.e. that any NITs which Gulf entered into for volumes reprocessed at Strachan would contain the condition that the purchaser would not contract for NGL extraction), was not a current practice. The Board passed this off to Gulf, NOVA and other shippers to resolve.

\section{E. Component-Tracking}

Gulf argued in the Application that it had a legal right to access its proportionate share of natural gas on the NOVA system at the Strachan Plant and that such access

\footnotetext{
81 AEC \& PCP Evidence, supra note 71 at 13.

$82 \quad$ Ibid; see also supra note 77 at $10,13$.

$83 \quad$ Supra note 77 at 6 .

st Ibid. at 13.
} 
could be determined by energy measurement (in gigajoules). This basis of measurement is used by industry for contractual, transportation and payment obligations.

While Gulf mentioned that energy measurement was the method which should be used, it recognized that part of its argument to the Board was that other parties were not prejudiced by the sidestreaming because the Strachan Plant owners had put into the NOVA system gas which contained more NGLs than average for the NOVA system. As a result, Gulf proposed a verification procedure to determine the NGL content of such gas. It stated:

[The Strachan Plant owners] are not at this point, asking that they be 'entitled' to remove all of these $\mathrm{C}_{3}+$ components, as acceptance of the verification methodology would otherwise entitle them to do, but rather, to illustrate to the Board that the participating Owners are actually diverting less than they contribute to the NOVA stream at Strachan. As such, this verification check is not the basis upon which the participating Owners are proposing to determine their proportionate share of the NOVA stream at Strachan which they seek to access. This is determined using the energy methodology. If, however, the Board finds that the $C_{3}+$ accounting methodology is necessary, it follows that Gulf and the participating Owners should also be entitled to sidestream sufficient NOVA volumes in order to access these $C_{3}+$ components from the NOVA system up to the approved volumetric inlet level of NOVA Gas. 85

This methodology required that such gas for reprocessing at the Strachan Plant be:

(1) owned or controlled by the participating owners;

(2) sourced as gas volumes physically delivered onto the NOVA system upstream of Strachan;

(3) sourced from Alberta Crown lands, not freehold lands;

(4) flowing under participating owner-controlled transportation arrangements on NOVA past the Strachan Plant; and

(5) from available (uncommitted) energy on the NOVA system. ${ }^{86}$

To meet these criteria the energy content of the gas must:

(1) not be contracted at a NOVA receipt point to third parties;

(2) not be subject to recognized third party obligations for extraction where the custody transfer point is at a downstream NOVA delivery point (i.e. TCGS contract);

(3) not be sold by a NIT where extraction rights are not retained by the participating owner;

(4) not be subject to downstream extraction contracts entered into by the participating owners directly; and

(5) not be sold or otherwise delivered off of the NOVA system upstream of Strachan. 
To determine the amount of energy available for straddle plant extraction, the Gulf methodology simply took all of the "available energy from downstream sources" and netted that amount back by subtracting:

(1) energy reprocessed at the Strachan Plant;

(2) energy contracted at downstream NOVA receipt points to third parties;

(3) energy subject to recognized third party obligations for extraction where the custody transfer point was a downstream NOVA delivery point;

(4) energy sold through NITs where the Strachan Plant owners did not retain the extraction rights;

(5) energy sold off of the NOVA system upstream of the straddle plants; and

(6) fuel and losses on the NOVA system.

Gulf provided an "Available $\mathrm{C}_{3}+$ Liquids Verification Calculation" for "illustrative" purposes. This involved each Strachan Plant owner:

(1) recording unit gas composition for gas injected into NOVA at all upstream NOVA receipt points;

(2) determining, on a receipt point basis, the gas volumes allocated to the Strachan Plant;

(3) calculating the aggregate volumes of NGLs in the owner's available gas on NOVA at Strachan; and

(4) reporting this data to the Strachan Plant operator.

The operator then:

(1) determines the actual NGL composition in the NOVA stream, based upon analysis of the NOVA Vetchland Compressor Station (the station immediately upstream of the Strachan Plant); and

(2) compares the aggregated plant owner's gas composition on NOVA at Strachan with the NOVA average composition at Vetchland and reports the aggregated data to the Board.

Gulf acknowledged the straddle plant owners concerns respecting "double-dipping" and stated:

While, at common law, the participating owners are within their rights to contract all of these Strachan sales gas volumes based on their proportionate share of the NOVA stream at the inlet point to the straddle plants, the participating Owners are prepared to commit not to contract for reprocessing at a downstream straddle plant, the energy reprocessed at Strachan (less the shrinkage). ${ }^{37}$

ANG and TCGS argued that Gulf's Application was deficient because it did not provide for a component-tracking mechanism. Once Gulf's gas was injected into the NOVA common stream, all NOVA shippers had an interest in it. NOVA did not 
covenant that the deliveries of gas off the system would have the same composition as the gas injected into the system. ${ }^{88}$

ANG characterized Gulf'stracking methodology as "unworkable" due to the physical flow of gas on NOVA. ${ }^{89}$ Gulf could not prevent such gas from being physically reprocessed at the straddle plants.

ANG argued that if Gulf could deem certain volumes to be available for sidestream processing at the Strachan Plant, other producers could do the same. This, combined with NITs, could mean the same volumes would be processed innumerable times. TCGS concurred on this point. It viewed the ability to use NITs as adding a "significant degree of complexity to the task of developing a composition tracking scheme." 90 The ability to use NITs would require a component tracking system of considerable complexity, which would increase the cost associated with such a system.

ANG also raised issues with respect to the mechanics of Gulf's proposal, specifically that Gulf proposed to combine and average the data of all Strachan Plant owners. This would make confirmation of such information difficult. Gulf also proposed an annual audit right which ANG viewed as inadequate and inconsistent with NOVA's move toward real-time balancing.

ANG argued that an equitable component-tracking methodology must:

(1) have industry-wide application;

(2) be understandable and predictable (i.e. NOVA shippers would be able to determine with a reasonable amount of certainty the quantity and location of liquids);

(3) keep track of all transactions to prevent double-dipping;

(4) keep track of all hydrocarbon components;

(5) recognize that upstreaming affects the ability to remove liquids downstream;

(6) balance competing demands of gas stream flows and liquids stream flows so all parties have a reasonable opportunity to access their liquids; and

(7) be cost effective. ${ }^{91}$

Amoco expressed similar concerns as ANG and TCGS respecting the need for a component balancing system and the difficulties of implementing it. Amoco estimated that for NOVA to provide on-line chromatographs and monitor all 867 receipt points and 167 delivery points on the system, it would cost as much as $\$ 75,000$ per location, excluding operating costs. This $\$ 77,500,000$ cost would be borne by all NOVA shippers, with the benefits of sidestreaming applying to only a few. ${ }^{92}$

ANG Intervention, supra note 71; TransCanada Intervention, supra note 77 at 9.

ANG Intervention, ibid. at 8.

lbid. at 10.

Ibid.

Supra note 73. 
The Board concluded that Gulf was proposing

to extract only the liquids content equivalent to that commingled by the owners upstream of Strachan and that Gulf could have removed if it had field deep-cut facilities available where the gas is injected into the NGTL system. The Board does not consider it significant whether Gulf recovers its liquids by reprocessing its share of the common stream at the straddle plants or whether it recovers them, or a portion of them, upstream at its Strachan gas plant. ${ }^{93}$

The Board decided, however, that it was possible that Gulf would extract more NGLs by sidestreaming on a volumetric basis at the Strachan Plant than it would be entitled to in the field. Since this could affect producers and straddle plant owners downstream, and since NGLs have different values, a component balancing system was required.

The Board stated that such a system should:

(1) be sufficiently detailed to provide confidence to shippers that it is fair;

(2) be flexible;

(3) provide monthly or other periodic balancing;

(4) be developed and maintained by Gulf; and

(5) be the result of consultation with other interested parties. ${ }^{94}$

\section{Conditions}

The Board approved Gulf's Application subject to four conditions:

(1) Gulf was restricted to reprocessing a daily volume of 5917 thousand cubic metres (210 million cubic feet) per day of NOVA sidestream gas. The practical effect of this condition was that Gulf would not be able to use the entire plant capacity (275 million cubic feet per day) for sidestreaming. The gas plant would be required to maintain at least sixty-five million cubic feet per day of raw gas processing. Gulf had indicated that this was its intention; ${ }^{95}$ however, Gulf refused to undertake that it would not, in the future, apply to have the 210 million cubic feet per day limit increased.

(2) Gulf was required to satisfy the Board on an annual basis that it was continuing to make reasonable efforts to optimize the use of the Strachan Plant for raw gas processing.

(3) Gulf was required, in conjunction with interested parties, to develop and maintain at its own expense, and comply with, a component-based monitoring system. The purpose of the system was to ensure that Gulf and other Strachan Plant owners did not remove more NGLs than they were entitled to on the

9) Decision D96-7, supra note I at 18.

\% Ibid.

"s Gulf's Response to ANG's Information Request No. I and to Amoco's Information Request No. 4. 
basis of "their own gas physically injected into the NGTL System upstream of the Strachan gas plant." 96

(4) Gulf was required to "implement whatever commercial arrangements are needed" to prevent double-dipping. The benefits of any reprocessing of volumes sidestreamed at the Strachan Plant were to be distributed among other shippers. ${ }^{97}$

\section{Potential Effects}

The potential effects of the Board's decision depend, to a large extent, on the interpretation of the conditions which were attached to the approval of Gulf's Application. These conditions may be seen as limiting the potential for future sidestream projects, or even as being a bar to such projects because of the difficulty of meeting the conditions. The potentially affected stakeholders are producers, facility owners, straddle plant owners and NOVA.

\section{A. Producers}

Some of the potential, and possibly inconsistent, effects on producers are:

(1) Sidestreaming will benefit producers because it will create greater competition among facility owners. Since sidestreaming will allow facilities which may otherwise have been mothballed to continue in operation, there will be greater competition for gas processing. This will lead to lower gas processing charges and hence a greater incentive for producers to explore and develop reserves in areas where facilities are sidestreaming. Without sidestreaming, incremental costs will be incurred as facilities are abandoned in order to connect existing fields to other processing facilities. ${ }^{98}$

(2) Sidestreaming will have a negative impact on producers because it will give facility owners greater leverage in negotiating gas processing rates. The sidestream volumes will act as a baseload for some facilities which will reduce the incentive for a facility owner to actively seek out opportunities to attract raw gas to the facility. The profit realized by sidestreaming will create a floor and in order to move gas through the facility, the raw gas processing rates will have to be in excess of the sidestreaming profits. ${ }^{99}$

(3) Producers who are not sidestreaming will be negatively affected because the NOVA common stream will have a reduced NGL component. With fewer NGLs to recover, there will be increased cost per unit of NGLs recovered and

Decision D96-7, supra note $I$ at 19.

Ibid.

Confer Consulting Ltd. Report (February 1996).

Purvin \& Gertz Inc., Assessment of Processing NOVA Gas versus Third Party Raw Gas at the Strachan Gas Plant (January 1996). 
the netbacks to producers under their straddle plant contracts will be reduced. ${ }^{100}$

(4) Producers will be negatively affected because as the straddle plant volumes decline, the shrinkage market will also decline.

(5) Producers will benefit because sidestreaming, and the possibility of sidestreaming, will force the straddle plant owners to be more competitive in their terms with the producers. ${ }^{101}$

(6) The Application was based on Gulf only reprocessing gas which it owned or controlled. Producers with reserves served by the Strachan Plant may be able to apply to the Board for a common processing order giving them the same rights to access the NOVA common stream for the purpose of reprocessing the gas for recovery of NGLs. ${ }^{102}$

(7) Producers would be affected by the calculation of gas cost allowance once the sidestream volumes are introduced into a facility. Allocation of costs to the facility's functional units would be an issue. ${ }^{103}$

(8) Sidestreaming provides a further source of potential revenue to producers. Sidestreaming would provide producers greater flexibility, since they would retain control of the NGL volumes which would otherwise be captured at the straddle plant level.

(9) If sidestreaming becomes prevalent, it could lead to component-tracking on NOVA. This would benefit those producers which have a rich gas feed into NOVA and hurt those producers whose gas feed is lean.

(10) If sidestreaming does lead to component tracking on NOVA, producers will pay for implementation and operation of the system, which could lead to reduced netbacks.

\section{B. FACILITY OWNERS}

(1) Sidestreaming could lead to increased competition for raw gas volumes, since some facilities which would otherwise be abandoned will potentially remain in business. These facilities, to the extent that they remain in the hunt for raw gas volumes, will continue to provide competition to the remaining facilities in a given area. 
(2) Sidestreaming could result in less competition for raw gas processing to other facilities in an area since, once sidestreaming occurs, the facility operator may be less inclined to pursue raw gas volumes.

(3) A facility may have its useful life extended by introducing sidestreamed volumes. The criteria which were suggested as being relevant in determining the potential for sidestreaming were:

(a) proximity to the NOVA mainline for significant quantities of upstream gas;

(b) excess capacity to accommodate sidestream gas;

(c) appropriate processing equipment, preferably a turbo expander that can remove enough NGLs to make reprocessing profitable;

(d) liquids-handling capabilities; and

(e) access to an NGL pipeline. ${ }^{104}$

(4) Facility owners who pursue sidestreaming may be able to eliminate some of the conditions that were imposed upon Gulf. For example, if producers who have production upstream of the plant are willing, it may be possible to process their gas on a fee-for-service basis. The Board's decision does not seem to prevent such reprocessing in principle.

(5) Facility owners may face a common processor application before the Board by producers in order to gain access to the NGL extraction portion of a plant for sidestreaming of their volumes in the NOVA common stream.

(6) As facilities in an area are rationalized, those facilities with sidestreaming capabilities may have an advantage.

(7) Sidestreaming will provide the following operational advantages to facility owners:

(a) the stream is predictable and reliable, as opposed to a raw gas stream;

(b) the sidestream is stable and predictable in heat content;

(c) there is one inlet, not several;

(d) raw gas streams may be declining and dependent on nominations, may have significant variation in by-products content, pose a greater danger to the environment, and increase the potential for damages; and

(e) raw gas feeds are subject to greater competition. ${ }^{105}$ 


\section{Straddle Plant OWNers}

(1) Straddle plant owners may not face any long-term negative effects from sidestreaming. The Board's decision states that the industry and the province have been well served by the straddle plant system, ${ }^{106}$ and the Board sees a viable straddle plant system as being in the public interest. ${ }^{107}$ This indicates that if there were to be further sidestream applications which would eventually result in significant effects upon the straddle plants, the Board would consider some protection for the straddle plants, perhaps in a form similar to the ethane policy.

(2) Sidestreaming reduces the quantity of recoverable NGLs. This could negatively affect the economics of straddle plants which could, in turn, result in them not being maintained or expanded to meet expansions of the NOVA system.

(3) The Board's decision requires that volumes sidestreamed at the Strachan Plant be reprocessed by the straddle plants, with the benefits being distributed among the other shippers. This requires the straddle plant owners to bear the administrative burden of such reallocation.

(4) Sidestreaming may force the straddle plants to renegotiate the terms of their arrangements with producers.

(5) Straddle plants will face increased costs in the processing of a leaner gas stream.

\section{NOVA}

NOVA did not participate in the hearing (although Novacor Chemicals Ltd. did). The following are potential effects on NOVA resulting from the Application:

(1) Additional administrative costs may result from sidestreaming. As gas is reinjected into the system following NGL extraction, the NOVA inventory will be affected. ${ }^{108}$

(2) There will be additional physical receipt and delivery points on the system, some of which will not be subject to the payment of the NOVA tariff. This will again increase the administrative burden on NOVA.

(3) The most significant potential impact on NOVA is the spectre of componentbalancing. If sidestreaming were to increase, there might develop a consensus that component-tracking is necessary or desirable. The creation of such a system would be expensive, time consuming and administratively difficult. 
(4) In discussing the practicality of conditional NITs, the Board recognized that such contracts were not currently in use. It indicated that it expected Gulf, NOVA and other shippers to ensure that future contracts are designed to deal with the concerns raised by the interveners. ${ }^{109}$ The restructuring of NITs could be a costly undertaking for NOVA if there is an indication from industry that such a restructuring should be carried out.

\section{CONCLUSION}

At this time, it is difficult to assess the long-term impact of the Board's decision. It is possible that the conditions the Board imposed upon Gulf - in particular the obligation to implement a component-tracking mechanism - may result in the approval being a pyrrhic victory for Gulf which is too difficult and expensive to execute.

As for other potential sidestreaming projects, to the extent that plant owners anticipate being subject to the same or similar conditions, that anticipation alone may be enough to convince them to forgo the sidestreaming option. 